\title{
The Role of Actin in Muscle Spasms in a Case Series of Patients with Advanced Basal Cell Carcinoma Treated with a Hedgehog Pathway Inhibitor
}

\author{
Natalie Teh $\cdot$ Liang Joo Leow
}

Received: September 21, 2020 / Published online: November 16, 2020

(C) The Author(s) 2020

\begin{abstract}
Basal cell carcinoma (BCC) is the most common cancer globally, with the incidence increasing worldwide by approximately $1 \%$ annually. While most cases of BCC can be treated surgically, advanced BCC often poses treatment challenges for patients unsuitable for, or refractory to, radiotherapy and surgery. Since the majority of cases of BCC demonstrate Hedgehog signaling hyperactivation, Hedgehog pathway inhibitors provide durable treatment options and improved clinical outcomes for patients with advanced BCC. One of the most common adverse events seen in patients taking Hedgehog inhibitors includes muscle spasms, which are hypothesized to occur because of calcium influx into the muscle cells. Here we present a case series of patients with muscle spasms during treatment with sonidegib and propose an alternate etiology related to increased actin expression.
\end{abstract}

N. Teh $(\bowtie)$

St Vincent's Clinical School, University of New

South Wales, Sydney, Australia

e-mail: natalie.teh@student.unsw.edu.au

L. J. Leow

Aesthetic Dermatology, Sydney, Australia
Keywords: Actin; Hedgehog pathway inhibitor; Muscle spasm; Sonidegib

\section{Key Summary Points}

Many cases of basal cell carcinoma (BCC) can be treated with surgery or radiotherapy successfully. However, in advanced BCC_-including locally advanced BCC and metastatic BCCsurgery and radiotherapy may be inappropriate and/or result in considerable morbidity or deformity.

Hedgehog pathway inhibitors (HHIs) were developed to block aberrant Hedgehog signaling found in most cases of BCC. Inhibition of the Hedgehog pathway is among the few pharmacologic treatment mechanisms available for patients with advanced BCC.

One of the most common adverse events observed in patients receiving HHIs is muscle spasms, hypothesized to result from noncanonical Hedgehog signaling causing calcium influx into the muscle cell.

We describe an alternate etiology of muscle spasms due to potentially increased actin expression in a case series of patients with advanced BCC. 


\section{DIGITAL FEATURES}

This article is published with digital features, including a summary slide, to facilitate understanding of the article. To view digital features for this article go to https://doi.org/10.6084/ m9.figshare.13187363.

\section{INTRODUCTION}

Basal cell carcinoma (BCC) is the most common cancer globally, with the majority of cases demonstrating increased activation of the Hedgehog signaling pathway [1]. Although most cases of BCC are treatable surgically, advanced BCC can result in significant morbidity due to destructive local spread [1]. Clinical subtypes of advanced BCC include nodular, superficial, morpheaform, infiltrative, micronodular, and basosquamous, with the latter four subtypes tending to demonstrate more aggressive behavior with a high recurrence rate and extensive local tissue destruction compared with the less aggressive nodular or superficial subtypes [1].

Treatment options for low-risk BCCs include surgical excision, superficial radiotherapy, electrosurgery, cryotherapy, curettage, intralesional and topical chemotherapy, topical immunotherapy, and photodynamic therapy [1]. For patients with advanced BCC (metastatic BCC [mBCC] and locally advanced BBC [laBCC]), additional options are often required to effectively treat tumors unsuitable for radiotherapy or surgery.

Inhibition of the Hedgehog signaling pathway is among the few pharmacologic treatment mechanisms available for patients with advanced BCC. The mechanism of action of Hedgehog pathway inhibitors (HHIs) involves selective inhibition of Smoothened, a protooncogene associated with overactivation of the Hedgehog signaling pathway-a key feature of BCC development [1]. Sonidegib (Odomzo ${ }^{\circledR}$; Sun Pharmaceutical Industries, Inc.; Cranbury, $\mathrm{NJ}$ ) is an HHI approved to treat adult patients with laBCC, which has recurred following surgery or radiotherapy, or those who are not candidates for surgery or radiotherapy [2, 3]. The safety data for approved HHIs indicate almost all patients experience treatment-emergent adverse events (AEs) during clinical trials, with the most common AEs including muscle spasms (66.4\%), alopecia (61.1\%), and dysgeusia $(57.3 \%)$ [4]. To date, muscle spasms are hypothesized to result from noncanonical Hedgehog signaling triggering calcium influx into the muscle cell [5]. Here we describe an alternate etiology of muscle spasms due to potentially increased actin expression in a group of patients with advanced BCC. This case series was conducted according to the ethical principles of the Declaration of Helsinki. All patients provided informed consent for publication of this report.

\section{CASE PRESENTATIONS}

Nine patients with advanced BCC presented to two dermatology offices in Sydney and Griffith, New South Wales, Australia, for treatment with sonidegib. The medical records of the patients were studied for the incidence of muscle spasms during treatment. The average age of patients was 56 years, and $55.6 \%$ were female. Of the nine patients, six had nonaggressive histologic subtypes of BCC (Table 1). Prior to treatment with sonidegib, eight patients were either biopsied for confirmation of diagnosis or presented with biopsy results, while one patient presented with incomplete clearance from Mohs surgery, having residual tumor and perineural invasion confirmed on paraffin sections. All patients instituted the same treatment protocol of oral sonidegib $200 \mathrm{mg}$ once daily. For this case series, patient treatment initiation dates ranged from 2 May 2018 to 16 January 2020. The average duration of treatment was 7 months, with one patient receiving ongoing treatment. Dysgeusia was the most common AE experienced with $44.4 \%(n=4)$ of patients reporting, followed by fatigue $(22.2 \%)$, loss of appetite (11.1\%), hyperhidrosis (11.1\%), arthralgia (11.1\%), and alopecia (11.1\%). No AE was reported in $33.3 \%$ of patients. The three patients with aggressive BCC subtypes (morpheaform and infiltrative) experienced muscle 
Table 1 Patient demographics and clinical characteristics

\begin{tabular}{|c|c|c|c|c|c|c|c|c|}
\hline $\begin{array}{l}\text { Patient } \\
\text { number }\end{array}$ & $\begin{array}{l}\text { Age } \\
\text { (years) }\end{array}$ & Sex & Tumor subtype & $\begin{array}{l}\text { Tumor } \\
\text { location }\end{array}$ & $\begin{array}{l}\text { Duration of } \\
\text { treatment } \\
\text { (months) }\end{array}$ & $\begin{array}{l}\text { Previous } \\
\text { treatment }\end{array}$ & $\begin{array}{l}\text { Muscle } \\
\text { spasms }\end{array}$ & Adverse events \\
\hline 1 & 64 & M & Morpheaform & Scalp & 6 & None & Yes & None \\
\hline 2 & 45 & $\mathrm{~F}$ & $\begin{array}{c}\text { Nodular and } \\
\text { superficial }\end{array}$ & Nose & 8 & None & No & $\begin{array}{l}\text { Loss of appetite } \\
\text { (mild), } \\
\text { alopecia }\end{array}$ \\
\hline 3 & 53 & $\mathrm{~F}$ & $\begin{array}{l}\text { Nodulocystic and } \\
\text { superficial }\end{array}$ & Nose & 12 & None & No & $\begin{array}{l}\text { Dysgeusia, } \\
\text { hyperhidrosis }\end{array}$ \\
\hline 4 & 59 & M & Nodular & $\begin{array}{l}\text { Lower eyelid, } \\
\text { nose }\end{array}$ & 9 & None & No & Dysgeusia \\
\hline 5 & 66 & M & Nodular & Inner canthus & $5^{a}$ & None & No & None \\
\hline 6 & 75 & $\mathrm{~F}$ & Nodular & $\begin{array}{l}\text { Upper/lower } \\
\text { eyelids, } \\
\text { cheeks, } \\
\text { forehead }\end{array}$ & $2^{\mathrm{b}}$ & None & No & None \\
\hline 7 & 55 & M & Infiltrative & Upper lip & 3 & None & Yes & Dysgeusia \\
\hline 8 & 49 & $\mathrm{~F}$ & Nodular & Scalp & 13 & None & No & $\begin{array}{l}\text { Dysgeusia, } \\
\text { arthralgia } \\
\text { (mild), } \\
\text { fatigue (mild) }\end{array}$ \\
\hline 9 & 36 & $\mathrm{~F}$ & $\begin{array}{l}\text { Morpheaform and } \\
\text { infiltrative with } \\
\text { perineural } \\
\text { invasion }\end{array}$ & $\begin{array}{l}\text { Right } \\
\text { eyebrow }\end{array}$ & 8 & $\begin{array}{c}\text { Mohs surgery } \\
\text { (incomplete } \\
\text { clearance) }\end{array}$ & Yes & $\begin{array}{l}\text { Fatigue } \\
\qquad \text { (moderate) }\end{array}$ \\
\hline
\end{tabular}

a Patient continuing treatment

b Patient treated until death due to unrelated cause

spasms, while none of the patients with nonaggressive subtypes reported muscle spasms during the course of treatment.

\section{DISCUSSION}

Among approved HHIs, muscle spasms are one of the most common AEs reported [4]. In the phase 2 Basal Cell Carcinoma Outcomes with LDE225 (sonidegib) Treatment (BOLT) study, $51.9 \%$ of patients receiving sonidegib $200 \mathrm{mg}$ experienced muscle spasms [6]. However, the study patient population consisted primarily of laBCC $(n=194)$ rather than $\operatorname{mBCC}(n=36)$ cases, and $>56 \%$ of patients had aggressive histologic tumor subtypes [6]. Similarly, in the phase 2, long-term safety and efficacy of vismodegib study (ERIVANCE), $57 \%$ of all tumor subtypes were aggressive. Overall, $71.2 \%$ of patients experienced muscle spasms [7].

During this case series, AEs were closely monitored and reported throughout treatment, and our findings do not support muscle spasms as a common $\mathrm{AE}$ among patients with nonaggressive histologic tumor subtypes. Of the nine 
patients included, the three patients with aggressive tumor subtypes experienced muscle spasms, while the six patients with nonaggressive tumor subtypes reported no muscle-related AEs. Consequently, the etiology and pathogenesis of muscle spasms in patients taking HHIs require further investigation.

Muscle spasms are often described as persistent, involuntary muscle contractions [8]. The physiology of muscle contraction begins with an impulse delivered to presynaptic nerve terminals, releasing the neurotransmitter acetylcholine and activating a muscle action potential (AP) via the postsynaptic receptors [9]. The AP then releases calcium, which binds to a regulatory protein and triggers the reaction of actin and myosin to shorten the muscle fibers, resulting in muscle contraction [9]. Although the exact mechanism of action causing muscle spasms in patients receiving HHIs is unknown, it is thought that noncanonical Smoothened activation promotes the opening of plasma membrane calcium channels in muscle cells [5]. However, we propose an alternative etiology for muscle spasms in patients with advanced BCC with aggressive tumor subtypes. The Hedgehog signaling pathway regulates E-cadherins and adherens junction protein expression, which is essential for maintaining the integrity of the actin cytoskeleton [10]. Actin, the main component in contractile microfilaments, is crucial for cell mobility and transport [11]. Alphasmooth muscle actin ( $\alpha$-SMA), a cytoskeletal protein isoform of actin, is found in $67 \%$ of micronodular, $62 \%$ of morpheaform, and $0 \%$ of nodular BCCs [11]. Micronodular BCCs with increased $\alpha$-SMA expression are associated with a greater incidence of deeper tissue and neural invasion [11]. The expression of $\alpha$-SMA within the stroma of BCCs is thought to be a marker for stromal myofibroblasts, which are significantly correlated with tissue invasion and aggressive tumor behavior [11]. Myofibroblasts play an essential role in cell contractility, modulating the formation of extracellular matrix and assembling fibronectin-serving as a scaffold to bind collagen and other extracellular matrix proteins (Fig. 1) [12]. Moreover, myofibroblast assembly of fibronectin may influence peripheral nuclear positioning of skeletal muscle cells,
Fig. 1 Myofibroblast properties [13]. Reprinted with permission from van Caam A, et al. Unraveling SSc Pathophysiology; The Myofibroblast. Front Immunol. 2018;9:2452. Published 2018 Nov 13. https://doi.org/10. 3389/fimmu.2018.02452. Myofibroblasts produce ECM factors and contain contractile stress fibers comprising of a-SMA. They are closely associated to neighboring cells and the ECM within their environment through focal adhesions and adherens junctions. $\alpha-S M A$ alpha-smooth muscle actin; $C T G F$ connective tissue growth factor; $E C M$ extracellular matrix; $E D A$ extra domain A; $F A K$ focal adhesion kinase; $I L$ interleukin; $L H 2$ lysyl hydroxylase-2; $P L O D 2$ procollagen-lysine, 2-oxoglutarate 5-dioxygenase 2; $R G D$ arginylglycylaspartic acid; $T G F \beta$ transforming growth factor $\beta$; $V E G F$ vascular endothelial growth factor

which is crucial for proper muscle function. $\alpha$ SMA expression may affect the ability of myofibroblasts to assemble the extracellular matrix and fibronectin through potential reorganization of fibronectin adhesions and increasing cell surface binding sites [12]. Consequently, changes in $\alpha$-SMA expression may affect muscle cell contractility and function through stimulation of myofibroblasts, possibly resulting in muscle spasms. Thereby, the increased expression of actin within aggressive subtypes suggests actin may be linked to the increased incidence of muscle spasms found in patients with these BCC subtypes.

The Hedgehog signaling pathway appears to have a flow-on effect on muscle function through myofibroblast $\alpha$-SMA expression, with immunochemistry demonstrating a strong positivity of muscle-specific actin in BCCs [11]. Accordingly, inhibition of the Hedgehog signaling pathway results in decreased E-cadherin expression and disassociation of the E-cadherin/ $\beta$-catenin protein complex-disrupting the actin cytoskeleton, destabilizing adherens junctions, and influencing myofibroblast behavior [10].

The findings reported here provide an alternative explanation for the presence of muscle spasms among patients with aggressive vs. nonaggressive BCC subtypes during treatment with HHIs. Since greater levels of actin expression are found in aggressive BCC subtypes, inhibition of actin is potentially increased with 


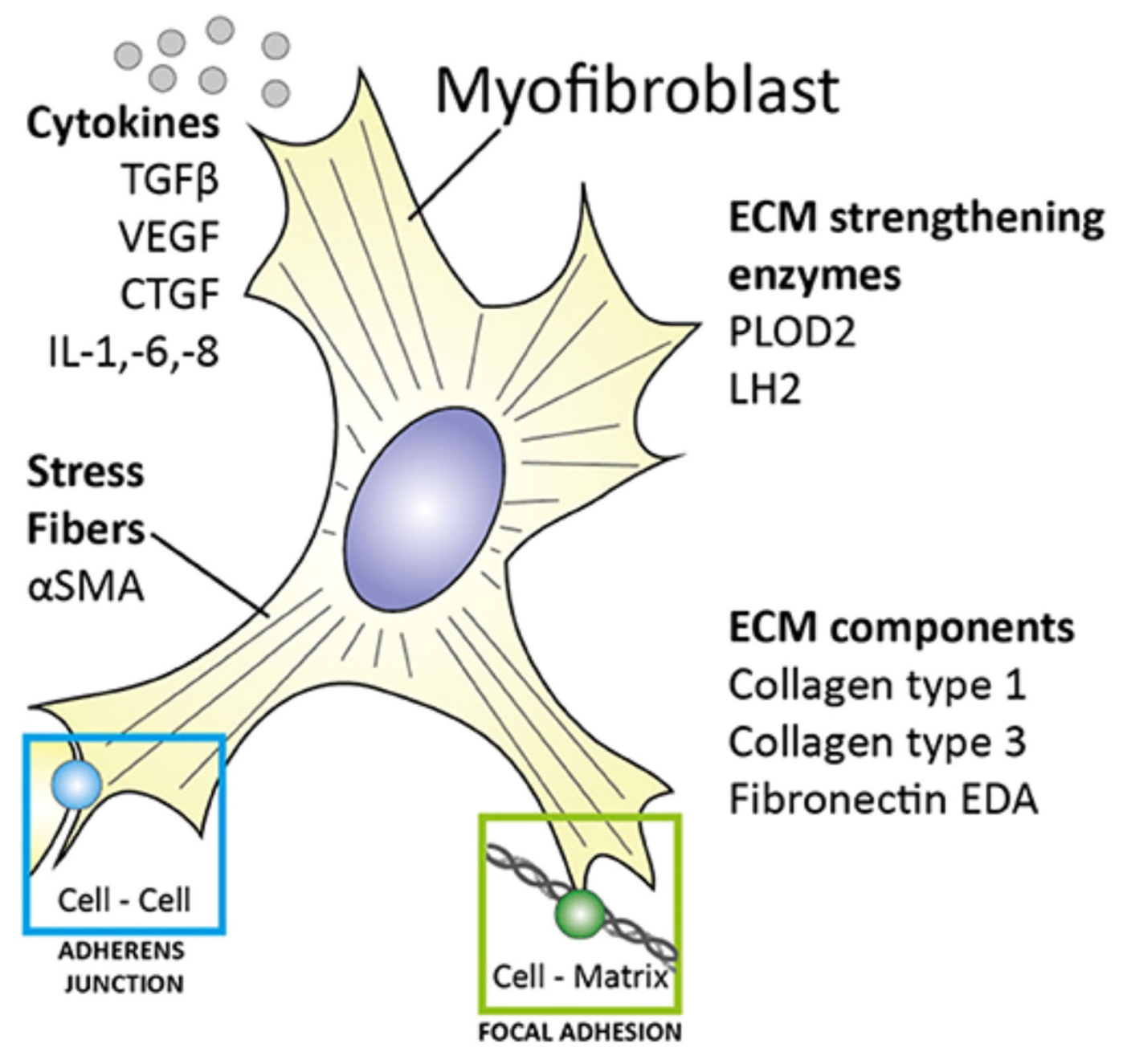

FOCAL ADHESION

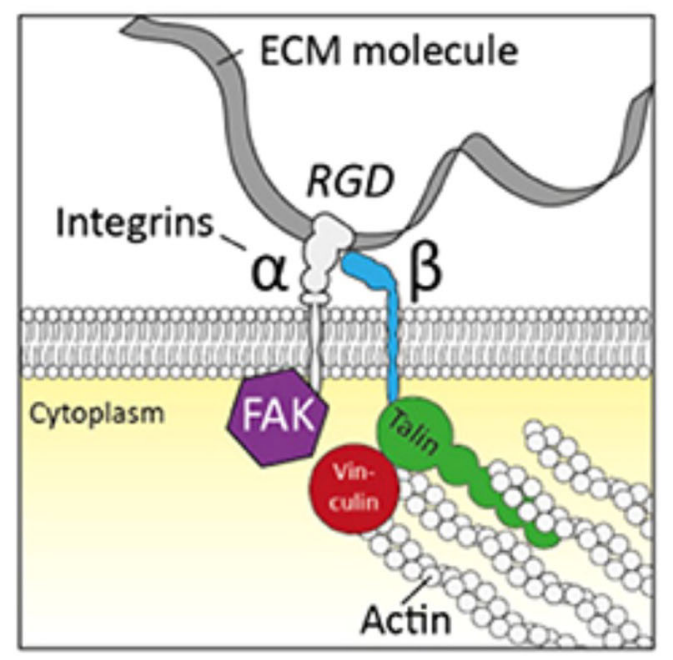

ADHERENS JUNCTION

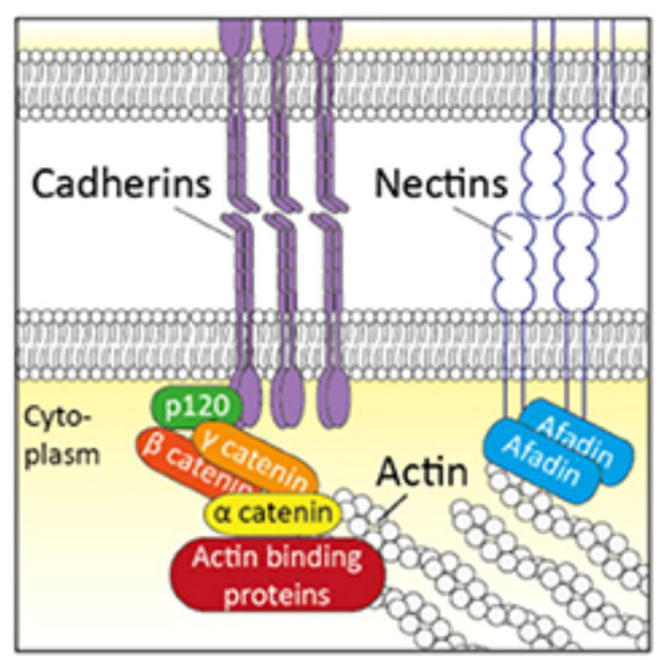


HHIs in these patients. Consequently, HHI-induced changes in $\alpha$-SMA expression and disruption of the actin cytoskeleton may potentially affect muscle function and lead to muscle spasms.

\section{CONCLUSIONS}

Our analysis of nine patients receiving treatment with an HHI for advanced BCC reveals an interesting finding in the incidence of muscle spasms between the two major subtypes of BCCs. Further examination of actin expression in patients receiving HHIs would be of value to understand better the role Hedgehog signaling pathway inhibition may have on muscle function in patients with aggressive vs. nonaggressive BCC subtypes.

\section{ACKNOWLEDGEMENTS}

The authors thank the participants of this case series.

Funding. This work and the journal's Rapid Service Fee were supported by Sun Pharmaceutical Industries, Inc.

Medical Writing, Editorial, and Other Assistance. Medical writing and editorial assistance were provided by Zehra Gundogan, VMD, of AlphaBioCom, LLC, under the direction of the authors and was funded by Sun Pharmaceutical Industries, Inc.

Authorship. All listed authors meet the criteria for authorship set forth by the International Committee for Medical Journal Editors and have significantly contributed to, seen, and approved the final submitted version of the manuscript.

Disclosures. Natalie Teh has nothing to disclose. Liang Joo Leow has participated on an advisory board for and received honoraria from Novartis Pharmaceuticals Corp. and has received travel support from Eli Lilly, Janssen
Pharmaceuticals, and Sun Pharmaceutical Industries, Inc.

Compliance with Ethics Guidelines. This case series was conducted according to the ethical principles of the Declaration of Helsinki. All patients provided informed consent for publication of this report.

Open Access. This article is licensed under a Creative Commons Attribution-NonCommercial 4.0 International License, which permits any non-commercial use, sharing, adaptation, distribution and reproduction in any medium or format, as long as you give appropriate credit to the original author(s) and the source, provide a link to the Creative Commons licence, and indicate if changes were made. The images or other third party material in this article are included in the article's Creative Commons licence, unless indicated otherwise in a credit line to the material. If material is not included in the article's Creative Commons licence and your intended use is not permitted by statutory regulation or exceeds the permitted use, you will need to obtain permission directly from the copyright holder. To view a copy of this licence, visit http://creativecommons.org/licenses/by$\mathrm{nc} / 4.0 /$.

\section{REFERENCES}

1. Marzuka AG, Book SE. Basal cell carcinoma: pathogenesis, epidemiology, clinical features, diagnosis, histopathology, and management. Yale J Biol Med. 2015;88(2):167-79.

2. Sun Pharmaceutical Industries, Inc. ODOMZO ${ }^{\circledR}$ HIGHLIGHTS OF PRESCRIBING INFORMATION. https://www.odomzo.com/themes/custom/odomzo/ global/pdfs/pi.pdf. Accessed 13 Nov 2020.

3. Therapeutic Goods Administration. PI for ARTG 292262. https://www.ebs.tga.gov.au/ebs/picmi/pic mirepository.nsf/pdf?OpenAgent\&id=CP-2017-PI02511-1\&d=202011121016933. Accessed 13 Nov 2020.

4. Jacobsen AA, Aldahan AS, Hughes OB, Shah VV, Strasswimmer J. Hedgehog pathway inhibitor therapy for locally advanced and metastatic basal cell carcinoma: a systematic review and pooled analysis 
of interventional studies. JAMA Dermatol. 2016;152(7):816-24.

5. Teperino R, Amann S, Bayer M, McGee SL, Loipetzberger A, Connor T, et al. Hedgehog partial agonism drives Warburg-like metabolism in muscle and brown fat. Cell. 2012;151(2):414-26.

6. Dummer R, Guminski A, Gutzmer R, Dirix L, Lewis $\mathrm{KD}$, Combemale $\mathrm{P}$, et al. The 12-month analysis from Basal Cell Carcinoma Outcomes with LDE225 Treatment (BOLT): a phase II, randomized, doubleblind study of sonidegib in patients with advanced basal cell carcinoma. J Am Acad Dermatol. 2016;75(1):113-25.e5.

7. Sekulic A, Migden MR, Basset-Seguin N, Garbe C, Gesierich A, Lao CD, et al. Long-term safety and efficacy of vismodegib in patients with advanced basal cell carcinoma: final update of the pivotal ERIVANCE BCC study. BMC Cancer. 2017;17(1): 332.

8. Mense S. Muscle pain: mechanisms and clinical significance. Dtsch Arztebl Int. 2008;105(12):214-9.

9. Stern LZ, Bernick C. Muscle cramps. In: Walker HK, Hall WD, Hurst JW, editors. Clinical methods: the history, physical, and laboratory examinations. Boston: Butterworths. Copyright (c) 1990, Butterworth Publishers, a division of Reed Publishing; 1990.

10. Xiao C, Ogle SA, Schumacher MA, Schilling N, Tokhunts RA, Orr-Asman MA, et al. Hedgehog signaling regulates E-cadherin expression for the maintenance of the actin cytoskeleton and tight junctions. Am J Physiol Gastrointest Liver Physiol. 2010;299(6):G1252-65.

11. Christian MM, Moy RL, Wagner RF, Yen-Moore A. A correlation of alpha-smooth muscle actin and invasion in micronodular basal cell carcinoma. Dermatol Surg. 2001;27(5):441-5.

12. Torr EE, Ngam CR, Bernau K, Tomasini-Johansson B, Acton B, Sandbo N. Myofibroblasts exhibit enhanced fibronectin assembly that is intrinsic to their contractile phenotype. J Biol Chem. 2015;290(11):6951-61.

13. van Caam A, Vonk M, van den Hoogen F, van Lent $P$, van der Kraan P. Unraveling SSc pathophysiology; the myofibroblast. Front Immunol. 2018;9: 2452 . 